\title{
THE RIGHT TO A JURY TRIAL IN A STOCKHOLDER'S DERIVATIVE ACTION
}

A recent decision of the Ninth Circuit Court of Appeals, DePinto v. Provident Security Life Ins. Co., ${ }^{1}$ decided for the first time that a constitutional right to jury trial exists for a stockholder's derivative action. The decision was based upon the seventh amendment's expressly limited guaranty that "in suits at common law ... the right of trial by jury shall be preserved. . . . Traditionally, the amendment's historical reference has been read as granting a right to jury trial in civil actions identical or analogous to common law actions existing in 1791. The Supreme Court, however, confronted with fundamental changes in modern procedure, has recently suggested that a hypothetical test be applied to the amendment's historical reference. ${ }^{3}$ The Court thus projected the merger of law and equity into the historical conditions existing in 1791 and then applied the seventh amendment to this hypothetical context. Because the extent of permissible projection has not been clearly defined by the Court, certainty in the interpretation of the seventh amendment has been disrupted. But regardless of which view of the seventh amendment is adopted, DePinto appears to be a striking misapplication of either historical analysis.

The suit was instituted by a shareholder of United Security Life Insurance Company against certain of United's officers and directors, who were charged with fraud, negligence and breach of fiduciary duty in purchasing worthless shares of another corporation. ${ }^{4}$ The plaintiff filed a timely demand for a jury trial. He later attempted to withdraw this demand but the defendants refused

1. 323 F.2d 826 (9th Cir. 1963), cert. denied, 376 U.S. 950 (1964).

2. The seventh amendment reads:

In Suits at common law, where the value in controversy shall exceed twenty dollars, the right of trial by jury shall be preserved, and no fact tried by a jury, shall be otherwise re-examined in any Court of the United States, than according to the rules of the common law.

U.S. CoNst. amend. VII.

The seventh amendment creates no new right to trial by jury. 5 Mfoore, Federal Practice If 38.08 [6] at 90 (2d ed. 1951) [hereinafter cited as Mioore].

3. See text accompanying notes 49-50 infra.

4. After an initial judgment in favor of United against all the defendants in the United States District Court for the District of Arizona, the U.S. Court of Appeals for the Ninth Circuit reversed, holding that a merger of United into Provident Security Life Insurance Company had deprived the complaining shareholder of standing to sue. Niesz v. Gorsuch, 295 F.2d 909 (9th Cir. 1961). After a reconstitution and realignment of the parties, including the intervention as a plaintiff of a present Provident shareholder who had been a former United shareholder and the realignment of Provident as a defendant, the district court readopted its original decision. The court of appeals affirmed the district court's permission to the Provident shareholder to intervene as plaintiff and its holding that the remanded proceeding was not barred by the Arizona statutes of limitations. DePinto v. Provident Security Life Ins. Co., 323 F.2d 826, 830, 832 (9th Cir. 1963). The third question presented on appeal was whether the defendants had been deprived of their constitutional right to trial by jury. The Ninth Circuit's resolution of this question is the subject of this Note. 
to consent to this withdrawal. The plaintiff then moved under Rule 39 (a) (2) for a trial to the court on the ground that neither constitutional nor statutory right to trial by jury existed in a stockholder's derivative action. ${ }^{0}$ The defendants resisted this motion. ${ }^{7}$ The district court reserved decision on the motion, and announced that a jury would hear the case, but that its verdict would be considered advisory if the motion for trial to the court was ultimately granted. After the close of evidence, the jury considered the case and returned a general verdict against certain of the defendants in the sum of $\$ 20,000$. The district judge then granted the plaintiff's motion to strike trial by jury, accordingly treated the jury verdict as advisory, and entered judgment against each defendant in the sum of $\$ 314,794.19 .^{8}$ The basis of this ruling was that a stockholder's derivative action was "basically if not solely" equitable rather than legal in nature and, therefore, no right to trial by jury existed. ${ }^{0}$ The Court of Appeals for the Ninth Circuit reversed the ruling of the district court, and remanded for a new trial..$^{10}$

5. When trial by jury has been demanded as provided in Rule 38 , the action shall be designated upon the docket as a jury action. The trial of all issues so demanded shall be by jury, unless ... (2) the court upon motion or of its own initiative finds that a right of trial by jury of some or all of those issues does not exist under the Constitution or statutes of the United States.

FED. R. CIv. P. 39(a) (2).

6. No federal statute establishes a right of trial by jury in a derivative action. DePinto v. Provident Security Life Ins. Co., 323 F.2d 826, 834 (9th Cir. 1963).

7. Although the defendants had not demanded trial by jury they were entitled to rely on the plaintiff's demand. FED. R. Crv. P. 38(d) ; 5 MoORE If 38.45, at 343-44.

8. The opinion of the district court is not reported. It may be found in Petition for a Writ of Certiorari, pp. 1a-8a, Provident Security Life Insurance Co, v. DePinto, 376 U.S. 950 (1964).

The opinion contained three related rulings; each was apparently intended to provide independent support for the result. First was a ruling that the jury verdicts were stpported by neither evidence nor legal principle and therefore "hereby are set aside and given no effect." Id. at 2a. Second was the ruling that the jury verdicts should be treated as advisory only, since the suit was equitable rather than legal. Third was the grant of the directed verdict for the plaintiffs, the effect of which was to substitute for the jury's assessment of damages a figure almost twenty times higher. The stated basis for this grant was that the evidence established "beyond reasonable challenge" and with "no substantial cvidence to the contrary" a loss of assets to the corporation of a minimum of $\$ 314,794.19$. Id a at $6 \mathrm{a}-7 \mathrm{a}$.

9. The district court opinion stated:

Under federal rules and procedure, determination of the right to jury trial depends upon whether the issues to be tried are cognizable in law or in equity .... . From their earliest recognition, stockholders' derivative actions have been regarded and treated as sounding in equity and not as actions at law. [Citation omitted] The present suit is solely and only a stockholders' derivative action. Therefore, as a proceeding basically if not solely in equity, the case was not triable by jury as a Id. at $3 \mathrm{a}$. matter of right to any of the defendants now demanding same.

10. DePinto v. Provident Security Life Ins. Co., 323 F.2d 826, 839 (9th Cir. 1963). The court of appeals also reversed the trial court's alternative holding and judgment which granted plaintiff's motion for a directed verdict, although this ruling by the district judgo had apparently been entered under the assumption that the defendants were entitled to a 
The mandate of the seventh amendment is founded, of course, upon the division of the English and American legal systems into separate law and equity jurisdictions, each with different procedures, remedies, and techniques for fact-finding. With few exceptions, actions cognizable in the courts of common law were triable to a jury, while in equity there was no right to jury trial. ${ }^{11}$ Although the American federal system did not adopt the English organization of wholly separate court systems, ${ }^{12}$ the English distinctions concerning the right to jury trial were preserved as a result of the distinct law and equity procedures which were applied in the federal courts. ${ }^{13}$ Where analysis of modern actions reveals a single historical counterpart, which is readily identifiable as having been within the jurisdiction of common law or of equity - such as a suit for damages for breach of contract or a bill to enjoin the continuance of a nuisance - the problem of jury trial has been the relatively simple one of correct historical analysis. ${ }^{14}$ If the modern action fits the pattern of an action at common law, there is a right to jury trial; if the action, on the other hand, is characteristic of an equitable bill, no right to jury trial is preserved. Most of the difficult jury trial problems in the merged federal practice have resulted from the combination of legal and equitable jury trial. This judgment had assessed liability against each of the defendants for $\$ 314$,794.19, despite the jury's exoneration of two of the defendants and assessment of only $\$ 20,000$ liability against the remaining defendants. Drawing an analogy to the serenth amendment's prohibition of additur in federal practice, Dimick v. Schiedt, 293 U.S. 474 (1935), the court of appeals held the seventh amendment similarly prohibited an award of damages in excess of a jury verdict in a suit triable by right to a jury where a jury had been in effect, demanded and had heard the case. DePinto v. Provident Security Life Ins. Co., 323 F.2d 826, 837-38 (9th Cir. 1963). Only the trial court's action in setting aside the verdict was thus left intact by the court of appeals, and the effect of the decision was to grant a new trial.

11. 5 MTOORE If 38.02[1], at 8-9. The history of the development of the jury is traced in 1 Holdsworte, A History of Evalish Law 312-50 (6th rev. ed. 1938).

12. 2 MOORE $\llbracket 2.03$.

13. 5 MOORE $\int 38.02[2]$. The guaranty of jury trial according to an historical test is of questionable functional validity in a merged procedure. Historically, the division between law and equity was not the result of an attempt to classify issues according to their suitability for trial to a jury or court. Generally, the chancellor's acceptance of jurisdiction was influenced by factors such as the availability of specific remedies, evidentiary flexibility, or the possibility of avoiding multiple suits. In addition, the acceptance of certain disputes by the courts of law or equity was often dictated by the political struggle between King and Parliament. James, Right to a Jutry Trial in Cizil Aclions, 72 YALE L.J. 655, 661-62 (1963). The seventh amendment has, nevertheless, elevated the historical distinction between law and equity to a constitutional command in determining the question of mode of trial.

14. The analysis is often complicated by the lack of a rigid barrier between law and equity and the continual process of borrowing, and consequent overlap, between jurisdictions before the adoption of the constitutional provision. James, supra note 13, at 658-61. But where the line between law and equity is generally, if not specifically, definable, the characterization of an action as legal or equitable normally disposes of the question of mode of trial. 
claims in a single action, ${ }^{15}$ and from the compulsory interposition of legal and equitable counterclaims without regard to the legal or equitable nature of the complaint. ${ }^{16}$ In these cases the guaranty of the seventh amendment must be separately applied to each element of the modern action which would have been a separate suit at law or in equity, and then a determination must be made as to sequence of trial.

The threshold question for the Ninth Circuit in DePinto was, therefore, the historical determination of whether a stockholder's derivative action was a unitary action at law or in equity or a combination of formerly separate legal and equitable claims. The court devoted one paragraph to this issue.

A stockholder's derivative action is an invention of equity to supply the want of an adequate remedy at law to redress breaches of fiduciary duty. The aid of equity is needed in order to establish the shareholder's right to sue in the corporate stead. But the claim set up is that of the corporntion. ${ }^{17}$

The opinion then asserted that "therefore" the question of jury trial in $n$ derivative action depends on whether, had the claim been directly brought by the corporation rather than indirectly by the stockholder, the suit would have been cognizable at common law. ${ }^{18}$ Having made this conceptual distinction between the right of the shareholder and the right of the corporation, the court shifted its inquiry from the nature of the action to the nature of the allegations and of the remedy sought. The court read the complaint, which asked only for money damages, as being founded on allegations of gross negligence. An action brought by a corporation against its officers demanding money damages for negligence would historically have been heard in a court of common law and would have been triable by right to a jury. ${ }^{10}$ The court thus held that because the suit could have been brought by the corporation in a cause of action triable at law, and for a remedy available at law, the constitutional guranty of jury trial was applicable. ${ }^{20}$ Although the Ninth Circuit's analysis lacks the explicitness necessary to precise understanding, in focusing upon the nature of the corporation's hypothetical cause of action the court appears to have

15. FED. R. CIV. P. 18(a).

16. FEv. R. Crv. P. 13(a). Difficult problems of sequence of trial have led to attempted solutions from the "basic nature of the issue" test adopted by Professor Moore, 5 Moome $\llbracket 38.16$, to the Supreme Court's recent sweeping decision in Beacon Thealres, Inc. v. Westover that the right to jury trial of legal issues can never (except in undefined, and probably non-existent circumstances) be lost through prior determination of equitable issuct. 359 U.S. 500, 511 (1959).

17. Citations and footnote omitted. 323 F.2d at 836.

18. Ibid.

19. The court used the same historical analysis to determine the question of jury right in a corporate action based upon breach of fiduciary duty by officers. Since the jury had expressiy found the defendants innocent of fraud, the Ninth Circuit concluded that the finding of breach of fiduciary duty actually rested upon a finding of gross negligence. Then it held that when a breach of fiduciary duty rests on underlying negligence, tho question of breach is historically a jury question. 323 F.2d at 837 .

20. Id. at 836-37. 
treated a derivative suit as a combination of separable legal and equitable causes of action for purposes of analysis of the right to jury trial.

The implicit basis of DePinto - that a derivative action should be treated as a combination rather than a unitary action - appears to rest on a mistaken treatment of a conceptual doctrine of current corporate law as an historical fact. At the root of traditional corporate law is the theory of "the corporate entity" or the "concept of separate personality." In its simplest terms, this is an expression of the idea that at common law the corporation was considered an entity distinct and separate from its shareholders. ${ }^{21}$ The fundamental reason for such a notion was to provide an analytic basis to justify the freedom of shareholders from unlimited liability for corporate liabilities. 20 A seemingly logical result of these doctrines was the complementary notion that harm to the corporation did not confer any right of action upon a shareholder. 23 However, the potential for managerial abuse resulting from the refusal of the courts of common law to recognize shareholder rights of action led the courts of equity to assume jurisdiction over suits brought by stockholders to enforce a right of action running to the "separate personality" of the corporation." This historical development explains the "derivative" nature of shareholder actions; they are conceptualized as suits in which a shareholder merely sets in motion the adjudication of a cause of action belonging to the corporation. Professor Ballantine is typical of the corporate theorists who view derivative actions as including two distinct aspects: "(1) to enforce in equity the corporate duty to the shareholder and (2) to enforce in the same proceedings the basic or underlying corporate right of action."25 Thus, he refers to a shareholder suit as being "in effect a combination of two causes of action, a proceeding having a dual nature."26

Despite this analytic duality, statements of conceptual theory locate jurisdiction over derivative actions exclusively in equity in order to reconcile the historical existence of these suits with the concept of the separate corporate

21. See Latrin, Corporations ch. 2, § 1 (1959) [hereinafter cited as Latrin]; 2 Hornstetn, CoRporatron Law and Practice $\S 711$ (1959) [hereinzfter cited as Hos:STEIN]; Stevens, Corporattons § 10 (2d ed. 1949) [hercinafter cited as Stevens].

22. See, e.g., In re John Koke Co., 38 F.2d 232 (9th Cir. 1930), cert. denied, 282 U.S. 840 (1930).

23. "At law" the corporation is regarded as a unit; and "at law" therefore individual shareholders may not sue although damage to the corporation necessarily has reduced the value of the interest of each shareholder. The complaint of a sharcholder is maintainable in equity, where it has been recognized almost since the beginnings of the business corporation.

2 HORNSTETN \& 711 at 191.

24. Cohen v. Beneficial Industrial Loan Corp., 337 U.S. 541, 547-48 (1949); Prunty, The Shareholders' Derivative Suit: Notes on Its Derivation, 32 N.Y.U.L. Rev. 980 (1957).

25. BaLlantine, CoRporations $\S 151$, at 359 (rev. ed. 1946).

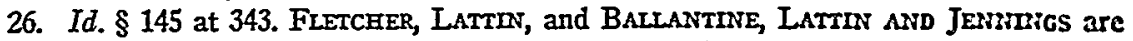
in rhetorical as well as theoretical agreement. FLETCHER § 5941 ; LATTIr ch. \&, § 2; BALlantane, Lattin \& Jennings, Cases and Mlateriats on Corporations 521 (2d ed. 1953). Stevens also subscribes to the dual analysis of derivative actions. STEvess $\S 170$. 
entity. ${ }^{27}$ Moreover, while the traditional analysis of derivative actions sets up a conceptual distinction between the right of the shareholder and the right of the corporation, the postulated "corporate cause of action" has never been thought to describe an actual historical class of suit which was recognized by courts of law. Instead, all commentators have recognized that historically equity has had exclusive jurisdiction over derivative suits and that the shareholder's right to set in motion the adjudication of a "corporate cause of action" has controlled the characterization of the entire action. Thus, it is generally agreed that there is no right to trial by jury in derivative suits. ${ }^{28}$

An additional basis for regarding the historical counterpart of the modern derivative suit as a unitary action, equitable in nature, is found in the examinn. tion of the early English cases which established the shareholder's right to petition a court of equity. These cases did not follow the conceptual separation of individual and corporate rights, nor the notion that a plaintiff in a derivative action vicariously asserts the right of the corporation. Instead, the decisions acknowledged that harm to the corporation necessarily reduced the interest of a complaining shareholder and recognized a direct trust relationship between corporate officers and shareholders, thereby providing a traditional foundation

27. 2 HORNSTEIN $\$ 711$. The conceptual foundation for equitable jurisdiction over derivative actions has been similarly stated in Glenn, The Stockholders' Sivil - Corporate and Individual Grievances, 33 YALE L.J. 580, 582 (1924). See also commentators cited note 26 supra.

28. Lattin, who follows the dual aspect conceptual analysis of derivative actions, sce note 26 supra, acknowledges the general characterization of the suit as equitable:

A derivative action is an invention of courts of equity and may be brought only in equity whether the corporate cause of action be in law or not. As far as corporate rights and defenses available against it are in issue, these issues are decided exactly as if the corporation were the plaintiff except the matter of jury trial, for the case being in equity there is no right to jury trial.

LATrin ch. 8, \&3.

Hornstein identifies the nature of the action as equitable and simply notes that "tho judge, without a jury, tries the case on the merits." 2 HORNSTEIN $\$ 730$.

Fletcher says: "An action by individual stockholders making the corporation a party defendant is equitable in nature, and plaintiffs are not entitled to a jury trial as a matter of right." 13 FLETCHER § 5931. In a later passage Fletcher discusses the problem raised by DePinto:

The stockholders' suit is always one in equity, at least unless otherwise provided by statute. But the fact that the stockholder gets into the litigation through a bill in equity does not change the fact that the right to be enforced is the legal right of the corporation. A stockholder cannot sue, as a representative of the corporation, by bringing an action at law, notwithstanding the corporation could have recovercd in an action at law. Even where the only relief allowable is a recovery of damages tho suit is nevertheless one in equity and not an action at law.

13 FLETCHER § 5944.

Pomeroy locates derivative actions as a branch of equity jurisdictions over quasi-trustees; equity recognizes that shareholders are ultimately the only beneficiaries. 4 PoneroY, EQUTTY JURISPRUDENCE $§ 1095$ (5th ed. 1941).

Moore identifies the nature of derivative actions as equitable and thereforc finds no right to trial by jury. 5 MOORE ff 38.38 [4]. 
for exclusive equity jurisdiction. ${ }^{29}$ Similarly, early American cases labelled the relationship between corporate officers and shareholders as one of trust. Thus, a shareholder could sue his "trustee" directly to enforce his equitable rights as beneficiary, even though the corporation itself retained a separate and concurrent right of action. ${ }^{31}$

The trust theory, however, was unable to reach cases in which a shareholder sued to enforce a corporate right against an outsider. ${ }^{32}$ Since such cases could

29. Prunty, supra note 24, at 980-85. Another basis of equity jurisdiction in the carly English cases was the representative nature of the suit. Common law rules of joinder vere initially inflexible and the class suit therefore became a branch of equity jurisdiction. Ibid. See generally 3 MOORE โ 23.02, 5 MOORE \{ 38.38[2].

30. The American case most frequently cited as the first shareholder's derivative action is Robinson v. Smith, 3 Paige Ch.R. 222 (N.Y. 1832). But the decision in this case appears to rest on an earlier dictum by Chancellor Kent in Attorney-General v. Utica Ins. Co., 2 Johns. Ch.R. 371 (N.Y. 1817). The holding in this carlier case actually involved a limitation on the power of equity - that equity lacked power to enjoin a corporation for violation of its franchise. But Chancellor Kent went on to help establish a power of equity in a dictum quoted in support of the holding in the Robinson decision:

[T] he persons who, from time to time, exercise the corporate powers may, in their character of trustees, be accountable to this Court for a fraudulent breach of trust; and to this plain and ordinary head of equity, the jurisdiction of this Court over corporations ought to be confined.

Attorney-General v. Utica Ins. Co., sipra at 389.

The Robinson decision applied Kent's dictum in its holding :

The directors are the trustees or managing partners, and the stockholders are the cestui que trusts, and have a joint interest in all the property and effects of the corporation. And no injury to the stockholders may sustain by a fraudulent breach of trust can, upon the general principles of equity, be suffered to pass without a remedy.

Robinson $\nabla$. Smith, supra at 232.

See also Taylor v. The Miami Exporting Co., 5 Ohio 162 (1831): "We think this Court, in a proper case made, has the power to compel an account from bank directors to their stockholders . . . and to set aside their fraudulent acts, if injurious to their principals." Id. at 168. Professor Prunty regards this case as "the first application, pro-shareholder, of the fiduciary principle to the facts of a typical derivative action." Prunty, supra note 24, at 988. See also 4 PoMreroy \$ 1095.

31. The fact that in this and other formative derivative actions the corporation was required as a necessary party does not indicate that sharcholders' rights vere regarded as secondary. The stated reason in the early cases was to prevent double recovery, suggesting a conception of the shareholder's action as "parallel rather than tangential to the corporate right." The corporate role in these early suits was simply that of the passive recipient. Prunty, supra note 24 , at 988-89.

32. According to Professor Prunty, the first of these cases was Forbes v. Whitlock, 3 Ed. Ch. 446 (N.Y. 1841). Prunty, supra note 24, at 990 . This was a suit by stockholders for breach of contract between a third party and the corporation. The court refused to stretch the trust relation to cover this situation, stating that shareholders "have not such an interest now as entitles them to ... prosecute on their individual account," and fearing that such a right "would be attended with endless difficulty and embarrassment." Forbes v. Whitlock, supra at 447-48. But the court limited the extent of the holding by noting that the shareholders have a direct right "when the directors, officers or managers, having the control of the corporation and its affairs, are guilty of misconduct, that amount [s] to a breach of duty as trustees." Ibid. 
not rest upon the equitable right of the shareholder to call his trustee (the corporate officer) to account, ${ }^{83}$ the courts denied shareholders direct rights against the defendant. Instead, the shareholder was required to assert derivative, or secondary, rights against the outsider in the name of the corporation." These cases originated the dual analysis stressed by current theories of derivative actions. Over a period of time the beneficiary-trustee doctrine was discarded in favor of a framework which places all shareholder stits in a single derivative category, regardless of whether the defendant is an officer, director or outsider. But despite this shift in analysis, equity maintained exclusive jurisdiction over all derivative suits.

Finally, the decisions of state and federal courts are in conflict with the holding of DePinto. In states where trial by jury is guaranteed by a constitutional provision similar to the seventh amendment, the majority of cases conclude that derivative actions are equitable in nature and therefore hold that there is no right to jury trial. ${ }^{35}$ Likewise, virtually every federal decision prior to DePinto conforms to the theory of origin of stockholder's suits advanced by the Supreme Court in Cohen v. Beneficial Industrial Loan Corp.:

Equity came to the relief of the stockholder, who had no standing to bring civil action at law against faithless directors and managers. Eqtity, however, allowed him to step into the corporation's shoes and to seek in its right the restitution he could not demand in his own.80

The consequence of this historical interpretation which places derivative suits within equity's jurisdiction was that, until DePinto, the guaranty of the seventh amendment had been held inapplicable to these actions. A characteristic

33. It appears that the right of a beneficiary to sue a third party when the trustee had a right of action but refused to sue was not yet mature. 3 Scorr oN TrusTs $\S 282.1$ (2d ed. 1956).

34. The confusion of the cases which established the right of the shareholder to stet to enforce a corporate right against an outsider is illustrated by the extensive opinion of the Supreme Court in Dodge v. Woolsey, 59 U.S. (18 How.) 331 (1855). In order to establish this right, it was necessary to integrate the breach of trust notion of the Robinson case with the theory of the lack of interest of shareholders in corporate rights against third parties of the Forbes case. The result was the secondary or derivative right of the shareholder to enforce the adjudication of a right of action in the corporation. Dodgc v. Woolsey, supra at 343-44.

35. E.g., Goetz v. Manufacturers' \& Traders' Trust Co., 154 Misc. 733, 277 N.Y. Supp. 802 (Sup. Ct. 1935) ; Metcalf v. Shamel, 166 Cal. App. 2d 789, 333 P.2d 857 (1959); Morton v. Morton Realty Co., 41 Idaho 729, 241 Pac. 1014 (1925); Neff v. Barber, 162 N.W. 667 (Sup. Ct. Wis. 1917); Steinway v. Griffith Consol. Theatres, 273 P.2d 872 (Sup. Ct. Okla. 1954).

36. 337 U.S. 541,548 (1949). Cf. Koster v. Lumbermens Mut. Cas. Co., 330 U.S. 518, 522 (1947); Meyer v. Fleming, 327 U.S. 161, 167 (1946); Hawes v. Oakland, 104 U.S. 450 (1881); Dodge v. Woolsey, 59 U.S. (18 How.) 331, 341-44 (1855).

The equitable nature of derivative actions was reflected in the adoption of Equity Rule 94 in 1882, and Rule 27 of the Equity Rules of 1912 as regulations for derivative actions. Rule 23(b) of the Federal Rules of Civil Procedure is the modern counterpart of these Equity Rules. 3 MOORE \23.15[1]. 
expression appears in Liken $v$. Shaffer, a case frequently cited for its discussion of the nature of the derivative suit:

A stockholder's derivative suit is an invention of the courts of equity and is recognizable only in equity and cannot be maintained at law. . . Even if the claim, if sued directly by the corporation, would be an action at law, yet, if enforced by means of a stockholder's derivative suit, it is prosecuted by an action in equity. ${ }^{37}$

Against this background of doctrine, history and precedent, it is not easy to understand the basis of the DePinto holding that the seventh amendment establishes a right to jury trial in any derivative action involving claims which, if brought directly by the corporation, would be considered legal in nature. ${ }^{33}$

37. 64 F. Supp. 432,441 (N.D. Iowa 1946).

38. One group of cases which presents an apparent deviation from the majority of cases involving the problem of jury trial in derivative actions is that in which sharcholders sue derivatively to enforce a corporate right of action for treble damages under the antitrust laws. The possibility of abuse is apparent if derivative actions, rather than corporate actions, were instituted to prevent a defendant's right to jury trial. Mr. Justice Holmes posed the troublesome question in Fleituram v. Welsbach St. Lighting Co.:

Of course the claim set up is that of the corporation alone, and if the corporation were proceeding directly under the statute no one can doubt that its only remedy would be at law. Therefore the inquiry at once arises why the defendants' right to a jury trial should be taken away because the present plaintiff cannot persuade the only party having a cause of action to sue....

240 U.S. 27,28 (1916). Holmes' answer was that "when a penalty of triple damages is sought to be inflicted, the statute should not be read as attempting to authorize liability to be enforced otherwise than through the verdict of a jury in a court of common law." Id. at 29. Thus, the holding was that a derivative action, as an action in equity in which there was no right of jury trial, could not be brought to enforce a corporate right to treble damages under the Sherman Act.

Later cases retreated from the rigid position of Fleilmann, and in 1953 the Second Circuit held in Fanchon \& Marco, Inc. v. Paramount Pictures, 202 F.2d 731 (2d Cir. 1953), that a derivative action based on a violation of the antitrust laws could be brought if the plaintiff presented a claim for equitable relief or simple damages. Although this was the extent of the holding, and the case was remanded to the district court for consideration of the plaintiff's claim for relief, Judge Clark was troubled by the problem of right to jury trial when the demand for judgment for treble damages arose under the Clayton Act. He prophesied: "the question of jury trial may never arise. . . Generally speaking it is wise not to borrow trouble as to questions which may remain dormant." 202 F.2d at 735. Not content, apparently, with his own advice, Judge Clark tried to reconcile the precedents. On one hand, he noted that stockholders' derivative actions were inventions of equity to redress breaches of fiduciary duty by corporate managers. On the other hand, he recognized that "[t]he Fleitmann case does hold specifically that a party is entitled to a verdict of the jury against him before he can be forced to pay treble damages under 15 U.S.C.A. $\S 15 . ” 202$ F.2d at 735. His conclusion was that:

The two major issues of right of the shareholder to sue and of violation of antitrust laws causing damage to the corporation can be tried side by side or othervise... that one may go to a jury while the other does not causes no difficulty.

$202 \mathrm{~F} .2 \mathrm{~d}$ at 735.

Judge Clarks dictum thus anticipates the analytic approach of DePinto: that a derivative action may involve separable issues for purposes of determining the right to jury trial. But the separation rests upon the specific statutory construction of Fleimamn rather than 
Language in the opinion, however, indicates that the Ninth Circuit relied for its holding upon two recent Supreme Court decisions which have expanded the coverage of the seventh amendment guaranty.

In the more significant of these decisions, Beacon Theatres v. Westovor, the plaintiff sought an injunction preventing defendant from instituting an antitrust action and a declaratory judgment that certain movie distribution contracts were not in violation of the antitrust laws. The defendant filed an answer and a counterclaim seeking treble damages against the plaintiff, and demanded a jury trial on the factual issues relating to the question of the violation of the antitrust laws. The trial court viewed the issues raised by the complaint as essentially equitable. It therefore directed that the common issue of both the complaint and the counterclaim - the lawfulness of the distribution contracts - be tried to the court. The Ninth Circuit upheld the trial judge's order, and held that the jury question must be answered by reading the complaint as a whole. Since the complaint asked for injunctive relief as well as for declaratory judgment, and since injunctive relief traditionally has been cognizable in equity, the court agreed with the district court that the complaint should be read as predominantly equitable..$^{40}$ Assuming the plaintiff had properly invoked equity jurisdiction, the case fits the historical pattern of cases in which $A$ has grounds for and seeks equitable relief before B institutes an action at law and B interposes a legal counterclaim. The rule in such cases had been that, while the legal claim was triable to a jury, the trial judge had discretion in determining trial sequence and could hear the equitable claim first, thus estopping relitigation on all facts common to both claims.4

The Supreme Court refused to apply this traditional rule in Beacon Theatres. The Court could have held that the plaintiff was simply trying to circumvent defendant's right to jury trial, that the claim was not cognizable in equity, and that, therefore, the trial judge's order was an abuse of discretion.42 But

upon the historical test of the seventh amendment. As Judge Clark had earlier pointed out, a derivative action based on a violation of the antitrust law, clearly a legal action if brought directly by the corporation, would have been cognizable by a court of equity if the plaintiff's demand for judgment had been either for equitable relief or simple damages. Thus, Judge Clark's dictum in Fanchon \& Marco which suggests a fragmented view of derivative suits is not strictly relevant to the problem of jury trial in DePinto, as no fecleral statute has been construed to guarantee a jury trial in a derivative action for simple damages on the negligence of corporate officers.

39. 359 U.S. 500 (1959).

40. Beacon Theatres v. Westover, 252 F.2d 864 (9th Cir. 1958).

41. American Life Ins. Co. v. Stewart, 300 U.S. 203 (1937); James, Right to a Jury Trial in Civil Actions, 72 YALE L.J. 655, 683 (1963). The framers of the declaratory judgment acts, like the authors of the Federal Rules, sought merely to preserve existing jury rights without expansion or diminution. BorCHARD, DeCLARATORY JudGMENT 399-404 (2d ed. 1941). Thus courts had followed the historical pattern: where declaratory relief did not fit into a traditional pattern of equitable relief, but was rather "an inverted lawsuit," parties had a right to jury trial. But if the declaratory action was a counterpart of a suit in equity there was no jury right.

42. The majority acknowledged the rule of American Life Ins. Co. v. Stcwart, 300 U.S. 203 (1937), that an equity court could have discretion to enjoin a lawsuit to provide 
the Court expressly assumed the trial court's premise that the complaint presented adequate grounds for equitable relief ${ }^{43}$ — traditionally the cue for the chancellor's discretion as to sequence of trial - and held that because the counterclaim presented a cause of action cognizable at law the parties had a right to jury trial on any factual issues common to the prayer for equitable relief and the legal counterclaim. The broad statement of the decision was that "only under the most imperative circumstances, circumstances which in view of the flexible procedure of the Federal Rules we cannot now anticipate, can the right to jury trial of legal issues be lost through prior determination of equitable claims."

The sweeping nature of this language has been underscored by the Supreme Court in Dairy Queen $v$. Wood, ${ }^{45}$ the second recent decision concerning the right to jury trial in civil actions. In Dairy Queen, as in Bcacon Theatres, the result is not surprising when read against the particular facts of the case. The plaintiff had attempted to create equitable jurisdiction by asking for injunctive relief and an accounting, although his claim for relief was essentially for damages resulting from a breach of contract. The Court held that "the constitutional right to trial by jury cannot be made to depend upon the choice of words used in the pleading." 46 But much of the Court's language in Dairy Queen, like that in Beacon Theatres, is broader than the facts of the case warrant. The trial judge had struck the demand for trial by jury upon the ground that

full determination of a case in one court. But a trial judge's order of trial sequence which denied jury trial of a legal counterclaim through collateral estoppel could be reversed on the ground of an abuse of discretion. Beacon Theatres v. Wood, supra note 39, at 505.

43. . . . assuming additionally that the complaint can be read as alleging the hind of harassment by a multiplicity of lawsuits which would traditionally have justified equity to take jurisdiction and settle the case in one suit, we are neverthcless of the opinion that, under the Declaratory Judgment Act and the Federal Rules of Civil Procedure, neither claim can justify denying Beacon a trial by jury of all the issues in the antitrust controversy.

Id. at 506 .

44. Id. at $510,511$.

The effect of Beacon Theatres has been to limit, if not eliminate, any use of discretion which removes a "legal issue" from jury trial. At least one Circuit has realized the sweeping implication of the decision. The Fifth Circuit recently stated:

It is therefore immaterial that the case at bar contains a stronger basis for equitable relief than was present in Beacon Theatres. It would make no difference if the equitable cause clearly out-weighed the legal cause so that the basic issue of the case taken as a whole is equitable. As long as any legal cause is involved the jury right it creates controls. This is the teaching of Beacon Theatres as we construe it. Thermo-stitch, Inc v. Chemi-Cord Processing Corp., 294 F.2d 486, 491 (5th Cir. 1961). This case presented a question similar to that decided in Beacon Thealres. Plaintif sued for a declaratory judgment that defendant's patents were invalid and had not been infringed. Defendant counterclaimed for patent infringement, fraud and antitrust violations and demanded a jury trial upon the factual issues of the counterclaim. The Fifth Circuit held that the trial judge was required by Beacon Theatres to submit these issues to a jury.

45. 369 U.S. 469 (1962).

46. Id. at $477-78$. 
any legal issues in the case were "incidental" to the equitable issues. In response, the Supreme Court held that Beacon Theatres meant that the right to jury trial of legal issues could not be lost even where the legal issues could properly be characterized as incidental to equitable issues.77 It is not clear how far this language in clarification of Beacon Theatres extends the Court's holding in Dairy Queen that the right to jury trial cannot depend upon "the choice of words used in the pleading." The language may mean that whenever a traditionally equitable claim involves even an incidental legal issuc there must be a right to jury trial of that legal issue. This reading would eradicate a major portion of equity jurisdiction for purposes of determining the right to jury trial, since legal issues will necessarily be involved in all cases in which equity has concurrent jurisdiction with law - the class of cases which equity hears because of the inadequacy of legal remedies.

However, the apparent rationale of decision in Beacon Theatres and Dairy Queen suggests that the opinions must be interpreted to reflect the fact that both suits were combinations of historically separable legal and equitable claims. Beacon Theatres and Dairy Queen fall within the historical pattern of cases in which equity would grant a remedy and then retain jurisdiction over the remainder of the suit despite the availability of legal remedies. These legal remedies were considered inadequate and therefore a basis for concurrent jurisdiction because of difficulties inherent in the separation of law and equity, which, it was thought, would cause the plaintiff irreparable injury if the case were dismissed..$^{48}$ The Supreme Court in Beacon Theatres focused its inquiry upon the justification for this branch of concurrent jurisdiction under the merged procedure of the Federal Rules.

Inadequacy of remedy and irreparable harm are practical terms, however. As such their existence today must be determined, not by precedents decided under discarded procedures, but in the light of the remedies now made available by the Declaratory Judgment Act and the Federal Rules. ${ }^{40}$ Beacon Theatres concluded that the merger of law and equity eliminated this instance of inadequacy of legal remedy by removing all possible barriers to the prosecution of the legal claim and thereby undercut equity's jurisdictional basis. ${ }^{50}$ Thus Beacon Theatres and Dairy Queen did not resolve the question

47. Id. at 473 .

48. E.g., Keith v. Henklemen, 173 IIl. 137, 50 N.E. 692 (1898). See James, supra noto 41 , at 670 .

49. Beacon Theatres v. Westover, supra note 39 , at 507.

50. Since in the federal courts equity has always acted only when legal remedies were inadequate, the expansion of adequate legal remedics provided by the Declaratory Judgment Act and the Federal Rules necessarily affects the scope of equity. Thus, the justification for equity's deciding legal issues once it obtains jurisdiction, and refusing to dismiss a case, merely because subsequently a legal remedy becomess available, must be re-evaluated in the light of the liberal joinder provisions of the Federal Rules which allow legal and equitable causes to be brought and resolved in one civil action.

Id. at 509. 
of jury trial under the seventh amendment by applying the traditional historical test. Instead these cases projected fundamental changes in modern conditions into the historical context to which the seventh amendment refers and hypothesized the division between law and equity jurisdiction which would have obtained had the modern procedures existed at that time.

This analysis of Beacon Theatres indicates that the Ninth Circuit was in error in relying upon the case for its holding in DePinto. Beacon Theatres is applicable to modern civil actions which involve a combination of historically separable suits in law and equity, whether the combination is a result of the merger of law and equity or is the descendant of a situation in which equity would have retained jurisdiction of a legal claim after the adjudication of a claim for equitable relief.51 Thus, for purposes of applying the Beacon Theatres rule, it is essential to stress the difference between the modern action whose issues individually reflect historically separable causes of action and the modern action which derives from a unitary cause of action. Stockholders' derivative actions are not, of course, a product of the merger of law and equity. Nor are they historically a combination of separable equitable and legal causes of action. Beacon Theatres and Dairy Queen have not empowered federal courts to ignore the historical division of law and equity in applying the guaranty of the seventh amendment. Since the DcPinto court did not purport to rest its decision upon changes in modern procedures affecting the characterization of stockholders' derivative suits as equitable in nature, the application of the Beacon Theatres doctrine to derivative actions is an unwarranted extension of the seventh amendment. ${ }^{\text {ta }}$

51. See Thermo-stitch, Inc. v. Chemi-Cord Processing Corp., 294 F.2d 486 at 491 (5th Cir. 1961), quoted at note 44 supra.

52. It may be objected that the analysis of this Note focuses solely upon an historical analysis of questionable relevance in a merged procedure. Because of the deficiencies of the historical test in providing a rational ordering of jury and court cases, see note 13 supra, it might be argued that a decline of historical rigidity accompanied by a functional awareness of the needs of modern judicial administration would be welcome. One obvious advantage of a flexible construction of the seventh amendment is the consideration which could thereby be afforded to nonconstitutional arguments for and against the right to jury trial in different types of litigation. However, there would be two objections to an attempt to justify the holding in DePinto on this basis. First, it is impossible to reach satisfactory conclusions from a functional analysis of the desirability of jury trial in civil actions generally or particularly in derivative litigation. There are few current debates in the law in which the arguments seem less susceptible of proof and more dependent upon intuitive judgments. For example, the argument that the jury is not a sufficiently efficient and discriminating trier of fact to effectively investigate complex derivative suits can be countered with the argument that application of common sense notions of fairness are entirely appropriate to the recurring questions of what constitutes a breach of fiduciary duty. A more basic objection concerns the legitimacy of functional analysis in a case involving the application of the seventh amendment. The amendment is strictly limited by its language to a preservation of the right to jury trial at common law. It represents a political compromise based upon the absence of consensus as to the proper functions of the jury. Since no consensus has developed since the adoption of the amendment it seems improper for courts to abandon the compromise. 